\title{
Facebook as a Tool for Learning L2 German
}

\section{Axel Harting \\ Hiroshima University}

\section{Reference Data:}

Harting, A. (2019). Facebook as a tool for learning L2 German. In P. Clements, A. Krause, \& P. Bennett (Eds.), Diversity and inclusion. Tokyo: JALT.

In this paper the results of an online survey regarding the usefulness of Facebook for $L 2$ learning will be presented. The survey was carried out with 118 L2 German learners in Japan. The results suggest that for most participants, Facebook is a suitable tool for improving their L2 skills because it enables them to establish or to maintain social contacts with native speakers and to have authentic opportunities to express themselves in the L2. The participants mentioned three particularly effective activities afforded by the social network: (a) reading $L 2$ posts on the newsfeed, (b) writing one's own posts and commenting on friends' posts, as well as (c) using the Messenger app for writing private messages in the L2. Most of the survey's participants noted an improvement of their reading and writing skills as well as an increase of their vocabulary and cultural understanding.

本稿は、第二外国語習得に対するFacebookの有用性に関するオンライン調査の結果を考察するものである。この調査は、 第二外国語としてドイツ語を学ぶ118名の日本人に対して実施された。調査結果から、参加者の大多数にとつて、Facebookは 学習言語を上達させることに適したツールであるということがわかる。これは、Facebookによって学習者が母語話者と社会的 な関係を構築または維持し、学習言語で考えを述べる本当の機会を持つことが可能になるからである。参加者が挙げた、とり わけ効果的であった活動は、学習言語での投稿を読むこと、自分自身で書くこと、友人の投稿にコメントをすること、学習言語 でプライベートメッセージを書くためにMessengerを使用することであった。調查参加者においては、読解と作文の技能、語 彙、文化的理解の向上が注目に值する。

he benefits of using Facebook or other social media for L2 learning have been pointed out in numerous studies. An overview of current research results can be found in Stevenson and Lui (2010), Wang and Vasquèz (2012), and Kent and Leaver
(2014). Several studies noted an increase of students' vocabulary and expression (Melor \& Hadi, 2012; Sim \& Pop, 2014) as well as an improvement of their writing skills (Shih, 2011; Dizon, 2016). In addition, positive effects for acquiring L2 pragmatics (Blattner \& Fiori, 2011; Harting, 2018) and even grammar (White, 2009) have also been observed. Most of the research in this field focuses on using social media within pedagogical settings, which requires participants to use such networks in not only legally and ethically but also in socially and culturally appropriate ways (Prichard, 2013).

Comparatively few studies have investigated how learners privately use social media for improving their L2 skills. The research carried out by Araya Ríos and Campos (2015) and Promnitz-Hayashi (2013) indicated an increase of learner autonomy by those students who use Facebook for L2 learning. Furthermore, comparative studies regarding private and course-based L2 messaging pointed out that learners seem to make more use of the L2 within private messaging than they do within teacher-initiated or teachercontrolled communication via social media (Leier \& Cunningham, 2016; Waragai et al., 2014). In his survey on informal Facebook learning experiences, Alm (2015) found that learners appreciate the opportunity of getting into touch with native speakers and participating in their own fashion in real L2 conversations.

In order to assist students in improving their L2 skills by using SNSs (Social Networking Services) extramurally, it has to be investigated in more detail how the participants wish to engage in the $\mathrm{L} 2$ through such networks. For this purpose, the survey described below was carried out in May 2018 with the online application LimeSurvey. Focusing on the particular interests of learners of L2 German in Japan the survey pursued the following research questions:

RQ1. What are the incentives of using Facebook to improve L2 German learning? RQ2. What kind of activities / functions of the network are used for this purpose? RQ3. a. How do learners rate the effectiveness of the network for $\mathrm{L} 2$ learning? b. What difficulties or limitations do they notice in this regard? 


\section{Data Collection and Analysis}

The online survey was carried out in May 2018 by means of the online application LimeSurvey. It was devised by the author and consisted of five sections containing a total of 15 questions (see Appendix). Apart from biographical information (Section 1), participants were asked to make a self-evaluation of their L2 skills (Section 2). Section 3 contained general questions concerning the use of individual Facebook functions. Sections 4 and 5 addressed participants' $\mathrm{L} 2$ use on Facebook and their attitudes towards studying German through SNSs.

In order to recruit participants for the voluntary survey, the study was announced in open and private Facebook groups, which are used by Japanese learners of German and often involve cultural and/or language exchanges. Apart from that, German teachers at Japanese universities were asked to make students who use Facebook aware of the survey. For one month, the questionnaire could be accessed through an Internet link, which guided the respondents through 15 questions, most of which contained answers to choose from. All 118 responses retrieved within that 1-month period were subjected to both quantitative and qualitative analyses. For questions that could be answered by figures, scales, or answer choices, percentages of respondents' answers were calculated (see Tables 1 to 4 in the results section). Questions, which required written comments, were subjected to a content analysis first, and then the frequency of individual statements within these comments was again calculated quantitatively (see Tables 5 to 7). Because the survey was conducted in the learners' native language (Japanese), participants' comments quoted in this article were translated into English.

\section{Results}

As the analysis of participants' biographical information revealed, a big proportion of them were female $(66 \%)$ and either under 30 years $(33 \%)$ or even under 20 years $(32 \%)$ old. Most studied German as part of their university education. Among respondents, $42 \%$ had studied German between 1 and 3 years; the percentages of those who had already studied 3 to 5 years, 5 to 10 years, or even more than 10 years were around 15\% each. More than two thirds of participants had already been to Germany, however most of them only for short stays of up to half a year. As far as participants' L2 skills are concerned, they were asked to make a self-evaluation of their speaking, writing, listening, and reading abilities according to three levels (see Table 1).
Table 1. Perceived L2 Level ( $N=118)$

\begin{tabular}{lcccc}
\hline Skill & Beginner & Intermediate & Advanced & N/A \\
\hline Speaking & $54.2 \%$ & $33.1 \%$ & $8.5 \%$ & $4.2 \%$ \\
Writing & $56.8 \%$ & $29.7 \%$ & $9.3 \%$ & $4.2 \%$ \\
Listening & $55.9 \%$ & $30.6 \%$ & $10.2 \%$ & $3.3 \%$ \\
Reading & $51.7 \%$ & $32.2 \%$ & $11.0 \%$ & $5.1 \%$ \\
Average & $54.7 \%$ & $31.4 \%$ & $9.8 \%$ & $4.2 \%$ \\
\hline
\end{tabular}

As the figures in Table 1 indicate, more than half of participants perceived themselves as beginners for all of the four language skills, just under a third as intermediate, and around $10 \%$ as advanced learners. As far as differences between the individual skills are concerned, the figures for each level deviate only slightly from the calculated averages.

In the survey, participants were also asked how often they performed various activities on Facebook. Table 2 lists the individual activities mentioned in the survey according to the frequency of participants' use.

Table 2. Frequency of Facebook Activities $(N=118)$

\begin{tabular}{lcccc}
\hline Facebook activity & Never & Occasionally & Often & N/A \\
\hline Writing messages to friends & $34.7 \%$ & $39.0 \%$ & $16.9 \%$ & $9.4 \%$ \\
Commenting on friends' posts & $34.7 \%$ & $51.7 \%$ & $7.6 \%$ & $6.0 \%$ \\
Answering friends' questions & $35.6 \%$ & $50.0 \%$ & $7.6 \%$ & $6.8 \%$ \\
Sharing pictures and videos & $43.2 \%$ & $44.0 \%$ & $5.9 \%$ & $6.9 \%$ \\
Writing one's own posts & $44.1 \%$ & $45.8 \%$ & $4.2 \%$ & $5.9 \%$ \\
Sharing links & $52.5 \%$ & $34.8 \%$ & $5.0 \%$ & $7.7 \%$ \\
Making status updates & $53.4 \%$ & $33.9 \%$ & $4.2 \%$ & $8.5 \%$ \\
Planning events & $73.7 \%$ & $12.7 \%$ & $1.6 \%$ & $12.0 \%$ \\
Playing games & $81.4 \%$ & $5.9 \%$ & $0.0 \%$ & $12.7 \%$ \\
Participating in quizzes & $81.4 \%$ & $5.9 \%$ & $0.0 \%$ & $12.7 \%$ \\
\hline
\end{tabular}


As the figures in Table 2 illustrate, among the individual activities listed in the survey, the most popular ones are writing messages to friends by using the Messenger app, commenting on friends' posts, as well as answering friends' questions concerning one's own posts. Adding the numbers of those who perform these activities often and occasionally amounts to almost or even more than $60 \%$. Around $50 \%$ also often or occasionally share pictures or videos and write their own posts. Around a third of respondents also occasionally share links and update their statuses, and the remaining activities listed in the survey (planning events, playing games, and participating in quizzes) are not performed at all by the majority of participants.

A particular reason for the survey was to find out to what extent participants use their L2 German on the network. In this regard, they were asked how many native speakers of the target language they have among their Facebook friends. Although a third of participants had no German Facebook friends, around $40 \%$ had between one and 10, and almost 30\% had more than 10 native speakers among their Facebook friends. Respondents were also asked how often they performed certain Facebook activities involving the L2. Table 3 lists the activities mentioned in the survey according to how often participants performed them.

Table 3. Frequency of L2 German Use on Facebook ( $N=118)$

\begin{tabular}{lcccc}
\hline Facebook activity & Never & Occasionally & Often & N/A \\
\hline Reading L2 posts & $31.4 \%$ & $50.0 \%$ & $14.4 \%$ & $4.2 \%$ \\
Writing messages in the L2 & $33.9 \%$ & $39.0 \%$ & $19.5 \%$ & $7.6 \%$ \\
Commenting on L2 posts & $43.2 \%$ & $45.8 \%$ & $1.6 \%$ & $9.4 \%$ \\
Writing one's own L2 posts & $44.9 \%$ & $42.4 \%$ & $7.6 \%$ & $5.1 \%$ \\
Using Facebook's translation tool & $50.0 \%$ & $37.3 \%$ & $5.9 \%$ & $6.8 \%$ \\
\hline
\end{tabular}

As the figures in Table 3 indicate, half of those who participated in the survey occasionally read German posts and almost $15 \%$ even read them often. Almost $40 \%$ occasionally write messages in their target language and just under a fifth write them often. To a slightly lesser extent participants also comment on $\mathrm{L} 2$ posts or write their own; combining the figures of those who perform these activities often and occasionally amounts to almost 50\%. The use of Facebook's translation tool, however, seems to be less popular. Half of the participants do not use it at all, and only about a third of them use it occasionally.
In order to ascertain the effect of using the target language on Facebook, participants were asked whether or not they perceived an improvement of individual language skills. Table 4 lists the individual skills mentioned in the survey according to the frequency by which participants answered affirmatively.

Table 4. Effect of Facebook Use on Individual L2 Skills ( $N=118)$

\begin{tabular}{lcccr}
\hline Skill & No & Don't know & Yes & N/A \\
\hline Reading comprehension & $9.3 \%$ & $12.7 \%$ & $69.5 \%$ & $8.5 \%$ \\
Cultural understanding & $7.6 \%$ & $17.8 \%$ & $63.6 \%$ & $11.0 \%$ \\
Command of L2 vocabulary & $11.9 \%$ & $16.1 \%$ & $62.7 \%$ & $9.3 \%$ \\
Writing & $15.3 \%$ & $16.1 \%$ & $57.6 \%$ & $11.0 \%$ \\
Understanding colloquial language & $22.0 \%$ & $14.4 \%$ & $54.2 \%$ & $9.4 \%$ \\
Understanding written language & $19.5 \%$ & $16.1 \%$ & $53.4 \%$ & $11.0 \%$ \\
Understanding L2 pragmatics & $14.4 \%$ & $19.5 \%$ & $53.4 \%$ & $12.7 \%$ \\
Mastering L2 grammar & $33.9 \%$ & $27.1 \%$ & $24.6 \%$ & $14.4 \%$ \\
Listening comprehension & $55.9 \%$ & $22.9 \%$ & $12.7 \%$ & $8.5 \%$ \\
Speaking & $54.2 \%$ & $25.4 \%$ & $11.0 \%$ & $9.4 \%$ \\
\hline
\end{tabular}

Regarding the impact of using the L2 on Facebook, more than two thirds of those who participated in the survey noticed positive effects on their reading comprehension. Almost two thirds each perceived a better understanding of German culture and an increase of their L2 vocabulary. More than half of the participants noted a positive effect on their writing skills, their comprehension of colloquial and written language, as well as an improvement of their pragmatic skills regarding the L2. Almost a quarter of participants also observed positive effects regarding the acquisition of $\mathrm{L} 2$ grammar. Probably due to the fact that communication on Facebook is mostly done in writing, only a small number of participants noted improvements regarding their listening comprehension and speaking skills.

Respondents were also asked to comment on which particular Facebook activities they consider effective for L2 learning. Table 5 lists individual activities that were mentioned in participants' comments by the frequency of their occurrence. The low frequency of items listed in Tables 5 to 7 can be explained by the fact that written 
comments within the survey were optional and that only a small proportion of participants replied to these questions.

Table 5. Effective Facebook Activities

\begin{tabular}{lc}
\hline Activities mentioned in participants' comments & Frequency \\
\hline Reading L2 messages & 10 \\
Exchanging L2 messages & 6 \\
Writing one's own posts in the L2 & 3 \\
Reading friends' L2 posts & 3 \\
Watching live broadcastings & 1 \\
Following group interactions & 1 \\
\hline
\end{tabular}

Regarding the effects on L2 learning, exchanging — and particularly reading - messages in the L2 were often mentioned in participants' comments. Some respondents also saw a benefit in reading friends' posts and writing their own: "I write my own posts in both languages, Japanese and German. In doing so, I can also receive comments from my German Facebook friends, and so I have additional opportunities to use the language." Other comments referred to more receptive activities, as in "I follow Facebook updates of German news broadcasters and those of my favourite ice hockey team."

Finally, respondents were asked to comment on positive and negative aspects of using Facebook for L2 learning. Table 6 lists points mentioned in participants' comments according to the frequency by which they occurred.

As the individual points listed in Table 6 illustrate, a major attraction of using Facebook for $\mathrm{L} 2$ learning seems to be to create and to maintain friendships with native speakers across the globe, to a slightly lesser extent also to get connected with other German learners in Japan. Furthermore, participants appreciated the chance to get into touch with the target language (in particular colloquial language) and culture and to have opportunities to express themselves in the L2. In their comments, they also praised the authenticity of the language they encountered on Facebook: "We can get familiar with colloquial German, which we normally don't find in textbooks or newspapers." Some comments also emphasised the accessibility of target language material: "It allows us to read news that we can't find in Japan(ese) and to share them!" One participant also appreciated being able to reflect on her own $\mathrm{L} 2$ acquisition process: "Thanks to the timeline, I have records of my own German learning history."

\section{Table 6. Merits of Using Facebook for L2 Learning}

\begin{tabular}{lc}
\hline Aspects mentioned in participants' comments & Frequency \\
\hline To get into touch with colloquial German & 8 \\
To find out what's going on in friends' lives & 7 \\
To maintain contacts with native speakers & 6 \\
To communicate across distances & 5 \\
To communicate with native speakers & 4 \\
To get into touch with German language and culture & 4 \\
To read news about Germany in real time & 3 \\
To exchange information with native speakers & 3 \\
To express myself in German & 3 \\
To get to know other learners of German in Japan & 2 \\
To have records of my own German learning process & 1
\end{tabular}

As far as negative aspects regarding the use of the medium are concerned, Table 7 lists some major points mentioned in participants' comments according to the frequency by which they occurred.

As can be seen in the comments listed in Table 7, participants' main concern regarding language learning through Facebook seems to be (a lack of) language correctness or appropriateness. This refers not only to their own contributions, but also to the language they encounter on the network. There is a potential danger of misunderstandings, which is expressed in the following comment: "In some posts sentences are too long and complicated, in others they are not explicit enough." In this regard, some participants also voiced uncertainty of being able to understand dialects and colloquialisms and to assess the level of formality of Facebook posts. Some even wondered if the language they read on Facebook is actually appropriate or formally correct. Other respondents also missed opportunities to receive feedback on their language use: "There is no feedback on mistakes as long as the meaning is transported." In addition, technical problems, such as typing the unique characters of the German alphabet as well as the appropriateness 
of Facebook's translation tool were also mentioned. A few participants also expressed insecurity regarding communication with strangers and voicing their own opinions on such a public platform.

Table 7. Negative Aspects of Using Facebook for L2 Learning

\begin{tabular}{lc}
\hline Aspects mentioned in participants' comments & Frequency \\
\hline Correct grammar and spelling & 8 \\
Understanding long and difficult posts & 3 \\
Understanding dialect and colloquialisms & 2 \\
Inadequateness of the translation tool & 2 \\
Risk of misunderstanding friends' posts and comments & 2 \\
Lack of feedback on mistakes & 2 \\
Input of German alphabet & 2 \\
Communicating with strangers & 1 \\
Sharing personal opinions on a public network & 1 \\
Assessing the degree of formality of the language used on Facebook & 1 \\
Insecurity of being understood correctly & 1 \\
\hline
\end{tabular}

\section{Summary and Discussion}

The results of the survey outlined in this article illustrate that many participants actively use Facebook to improve their L2 skills, which, according to Araya Ríos and Campos (2015) and Promnitz-Hayashi (2013), is an important incentive for developing more autonomy in the $\mathrm{L} 2$ acquisition process. According to participants' comments, benefits of using Facebook for L2 learning include establishing and maintaining contacts with native speakers and other learners of the target language, accessing target language contents, as well as achieving a deeper understanding of German language and culture, which confirms the findings of Alm (2015). Although some respondents appreciated the opportunity of getting into touch with nonstandard and colloquial language, others raised concerns about the formal correctness of the language they encountered on the network and the likelihood of misunderstandings. This implies that whether something is perceived as a merit or a difficulty of using Facebook for L2 learning depends on individual preferences and expectations concerning L2 study.
Among the most popular activities regarding $\mathrm{L} 2$ learning through Facebook are reading friends' posts and messages, as well as writings one's own. As far as the impact of Facebook on individual language skills is concerned, many respondents observed an improvement of their writing competence, which was also attested in the studies of Shih (2011) and Dizon (2016), as well as an expansion of their vocabulary and an increased ability to understand colloquial language, which reflect the findings of Melor and Hadi (2012) and Sim and Pop (2014). As documented in the studies by Blattner and Fiori (2011) and Harting (2018), a large proportion of respondents noted an increased awareness of $\mathrm{L} 2$ pragmatics. In addition, some participants also perceived progress in mastering L2 grammar, which was also observed in White's (2009) study. However, it has to be taken into account that perceived improvements in individual language skills are only based on the subjective assessments of the survey's participants. Further limitations of the survey lie in the fact that answer categories such as "often" and "occasionally" are in themselves rather subjective and cannot claim to yield precise results.

Finally, it has to be emphasized that participation in this survey was voluntary, and that the results may be biased towards learners who are interested in using social media (for language learning) anyway. Consequently, the findings cannot be used to make general claims about learners of German in Japan overall. Still, the data obtained in this study provide valuable insights into Facebook's potential and its limitations for L2 learning. We, as language teachers, should encourage students who are interested in increasing their knowledge of $\mathrm{L} 2$ language and culture through social media by designing learning activities that enable them to use the $\mathrm{L} 2$ in culturally and pragmatically appropriate ways.

\section{Bio Data}

Axel Harting wrote his PhD on German and Japanese email writing and is teaching German at Hiroshima University. His research fields are L2 writing, L2 pragmatics, and computer-assisted language learning.

\section{References}

Alm, A. (2015), Facebook for informal language learning: Perspectives from tertiary language students. The EUROCALL Review, 23(2), 3-18. https://doi.org/10.4995/eurocall.2015.4665

Araya Ríos, J., \& Campos, L. E., (2015). The role of Facebook in foreign language learning. Revista de Lenguas Modernas, 23, 253-262. https://doi.org/10.15517/rlm.v0i23.22349 
Blattner. G., \& Fiori. M. (2011). Virtual social network communities: An investigation of language learners' development of socio-pragmatic awareness and multiliteracy skills. CALICO Journal, 29(1), 24-43. https://doi.org/10.11139/cj.29.1.24-43

Dizon, G. (2016). A comparative study of Facebook vs. paper-and-pencil writing to improve L2 writing skills. Computer Assisted Language Learning, 29(8), 1249-1258. https://doi.org/10.1080/09588221.2016.1266369

Harting, A. (2018). Japanese students' attitudes towards using SNSs for learning German. In P. Clements, A. Krause, \& P. Bennett (Eds.), Language teaching in a global age: Shaping the classroom, shaping the world (pp. 43-50). Tokyo: JALT. Retrieved from http://jalt-publications.org/ articles/24275-japanese-students'-attitudes-towards-using-snss-learning-german

Kent, M., \& Leaver. T. (2014). An education in Facebook? Higher education and the world's largest social network. New York, NY: Routledge.

Leier, V., \& Cunningham, U. (2016), 'Just Facebook me': A study on the integration of Facebook into a German language curriculum. In CALL communities and culture-Short papers from EUROCALL 2016 (pp. 260-264). https://doi.org/10.14705/rpnet.2016.eurocall2016.572

Melor, Md. Y. \& Hadi, S. (2012). The effectiveness of Facebook groups on teaching and improving writing students' perceptions, International Journal of Education and Information Technologies, 6(1), 87-96.

Prichard. C. (2013). Training L2 learners to use Facebook appropriately and effectively. CALICO Journal, 30(2), 204-225. https://doi.org/10.11139/cj.30.2.204-225

Promnitz-Hayashi. L. (2011). A learning success story using Facebook. Studies in Self-Access Learning Journal, 2(4), 309-316.

Shih, R. C. (2011), Can Web 2.0 technology assist college students in learning English writing? Integrating Facebook and peer assessment with blended learning. Australasian Journal of Educational Technology, 27(5), 829-845. https://doi.org/10.14742/ajet.934

Sim, M. A., \& Pop, A. M. (2014), The impact of social media on vocabulary learning case study: Facebook. Annals of the University of Oradea, Faculty of Economics, 1(2), 120-130.

Stevenson, M. P., \& Liu. M. (2010). Learning a language with Web 2.0: Exploring the use of socia networking features of foreign language learning websites. CALICO Journal, 27(2), 233-259. https://doi.org/10.11139/cj.27.2.233-259

Wang, S., \& Vasquèz, C. (2012). Web 2.0 and second language learning: What does the research tell us? CALICO Journal, 29(3), 412-429. https://doi.org/10.11139/cj.29.3.412-430

Waragai, I., Kurabayashi, S., Ohta, T., Raindl, M., Kiyoki, Y., \& Tokuda, H. (2014). Context-aware writing support for SNS: Connecting formal and informal learning. In L. Bradley \& S. Thouësny (Eds.), CALL design: Principles and practice-Proceedings of the EUROCALL 2014 Conference (pp. 403-407). https://doi.org/10.14705/rpnet.2014.000253
White, J. (2009), The use of Facebook to improve motivation and academic writing. In Proceedings of the Third International Wireless Ready Symposium (pp. 28-32). Retrieved from http://wirelessready.nucba.ac.jp/white2009.pdf

Appendix

Survey

1) Age: _-

2) Gender:

3) Native language:

Section 1. German Skills

4) How long do you study German already?

__ year(s) __ month(s)

5) Have you ever stayed in Germany? If yes, how long? _ __ year(s) __ month(s)

6) How do you rate your German skills?

\begin{tabular}{|c|c|c|c|}
\hline & Beginner & Intermediate & Advanced \\
\hline \multicolumn{4}{|l|}{ Speaking } \\
\hline \multicolumn{4}{|l|}{ Writing } \\
\hline \multicolumn{4}{|l|}{ Listening } \\
\hline Reading & & & \\
\hline
\end{tabular}

7) Where do/did you study German?

language school online course university secondary school self study other

Section 2. Use of Facebook

8) How often do you use the following functions?

\begin{tabular}{l|l|l|l|}
\multicolumn{1}{c}{ never } & \multicolumn{1}{c}{ sometimes } \\
\cline { 2 - 4 } Writing one's own posts & & & \\
\cline { 2 - 4 } Commenting on posts & & & \\
\cline { 2 - 4 } Writing messages & & & \\
\cline { 2 - 4 } Sharing pictures/videos & & & \\
\cline { 2 - 4 } & &
\end{tabular}




\begin{tabular}{l|l|l|l|}
\multicolumn{1}{c}{ never } & \multicolumn{1}{c}{ sometimes } \\
\cline { 2 - 4 } Answering questions & & & \\
\cline { 2 - 4 } Quizzes & & & \\
\cline { 2 - 4 } Playing games & & & \\
\cline { 2 - 4 } Planning events & & & \\
\cline { 2 - 4 } Sharing links & & & \\
\cline { 2 - 4 } Status updates & & & \\
\cline { 2 - 4 } & & &
\end{tabular}

9) How many native speakers of German do you have among your Facebook friends? none 1 to $10 \quad$ more than 10

Section 3. Using German on Facebook

10) How often do you perform the following activities in German?

Writing your own $\mathrm{L} 2$ posts Writing messages in the $\mathrm{L} 2$ Using Facebook's translation tool Commenting on $\mathrm{L} 2$ posts Reading of $\mathrm{L} 2$ posts

\begin{tabular}{|l|l|l|}
\hline \multicolumn{1}{c|}{ never } & & \\
\hline & & \\
\hline & & \\
\hline & & \\
\hline & & \\
\hline & & \\
\hline
\end{tabular}

\section{Section 4. Effects on Learning German}

11) Do you perceive any positive effect on the following L2 skills by using Facebook?

Reading comprehension

Cultural understanding

Command of L2 vocabulary

\section{Writing}

Understanding colloquial language

\begin{tabular}{|l|l|l|}
\hline \multicolumn{1}{c|}{ no } & \multicolumn{1}{c|}{ don't know } & yes \\
\hline & & \\
\hline & & \\
\hline & & \\
\hline & & \\
\hline & & \\
\hline
\end{tabular}

Understanding written language

Understanding L2 Pragmatics

Mastering L2 Grammar

Listening comprehension

Speaking

\begin{tabular}{|c|c|c|}
\hline no & don't know & yes \\
\hline & & \\
\hline & & \\
\hline & & \\
\hline & & \\
\hline & & \\
\hline
\end{tabular}

12) Are there any concrete Facebook activities that you consider useful for learning German?

13) Do you have a particular method or ritual to use Facebook to improve your German?

14) What are positive aspects of using Facebook for learning German?

15) What are negative aspects of using Facebook for learning German? 